\title{
Barriers to the Transfer of Low-carbon Electricity Generation Technologies in Four Latin American Countries
}

\author{
Desgain, Denis DR; Haselip, James Arthur
}

Published in:

Energy Sources. Part B. Economics, Planning, and Policy

Link to article, DOI:

$10.1080 / 15567249.2014 .922136$

Publication date:

2015

Document Version

Peer reviewed version

Link back to DTU Orbit

Citation (APA):

Desgain, D. DR., \& Haselip, J. A. (2015). Barriers to the Transfer of Low-carbon Electricity Generation

Technologies in Four Latin American Countries. Energy Sources. Part B. Economics, Planning, and Policy, 10, 348-360. https://doi.org/10.1080/15567249.2014.922136

\section{General rights}

Copyright and moral rights for the publications made accessible in the public portal are retained by the authors and/or other copyright owners and it is a condition of accessing publications that users recognise and abide by the legal requirements associated with these rights.

- Users may download and print one copy of any publication from the public portal for the purpose of private study or research.

- You may not further distribute the material or use it for any profit-making activity or commercial gain

- You may freely distribute the URL identifying the publication in the public portal 


\title{
Barriers to the transfer of low-carbon electricity generation
}

\section{technologies in four Latin American countries}

\author{
Denis Desgain and James Haselip \\ UNEP Risø Centre, Department of Management Engineering, Technical University of Denmark, UN City, \\ Marmorvej 51, 2100 Copenhagen
}

\section{Introduction and methodology}

This article focuses on the structure and regulation of electricity markets and how this enables, or constrains, the transfer of prioritised low-carbon generation technologies to these markets, as expressed by governments in their national Technology Needs Assessments (TNAs). While the concept of 'technology transfer' is a largely top-down and politicallydriven agenda principally defined in the UN's Climate Change Convention (Article 4), and hence is lacking in detailed operational definitions, we do not seek to analyse the debate over what is, or can be considered, technology transfer. Instead we base our analysis upon the assumption that technology transfer, as a real-world process, refers to the trade in technologies, principally between the private sector of OECD and major 'emerging' economies and the private sector or government enterprises in less-developed countries (Karakosta et al., 2010; Popp, 2011). Most technologies can be categorised as either hardware or software, though it is often relevant, especially in complex systems such as grid-supplied electricity, to talk of the transfer of management and organisational 'know how', often referred to as 'orgware' (Boldt et al., 2012). Regardless of the form of technology, our second major assumption is that transfer cannot occur in the absence of clear financial incentives to invest and/or in the presence of financial barriers to purchase a specific technology. While there are a range of barriers to technology transfer, both financial and non-financial, we 
choose to focus our analysis on the financial and economic barriers, where 'financial' refers to 'internal' factors such as a project's rate of return (RoR) on investment and 'economic' refers to the wider context of a given economy.

We base our comparative analysis upon information gathered by the TNA project, funded by the Global Environment Facility (GEF) and implemented by UNEP and the UNEP Risø Centre since 2010. However there are limitations to using this information for scientific purposes since the TNA process is politically driven and hence the outputs are often aspirational and/or lacking in the provision of detailed, comparable, data. As such, we use the outputs of the TNAs for indicative purposes only and emphasise that our contribution to literature is limited to an analysis of these country-driven processes. However, they are significant in that they represent the formal conclusion of TNAs conducted by select nonAnnex I countries to the UNFCCC. When defining the key characteristics of the electricity markets for the four countries we draw upon a range of secondary data, as well as descriptions provided by countries themselves in the TNA process. Our comparative analysis also focuses upon the primary energy resource base of each country, how this influences the present-day electricity generation mix as well as the opportunities and prospects for investment in low-carbon alternatives.

\section{Electricity market structures and GHG emissions}

As part of the free-market or 'neoliberal' political wave that spread through much of Latin America from the late 1980s, many countries in the continent implemented electricity market reform policies. In nearly every country that has undergone electricity sector reform, generation has been liberalised with transmission and distribution markets operating as regulated (private) monopolies (Yi-Chong, 2006). Indeed Latin America was the major recipient of electricity sector liberalisation policies, where private investment totalled US\$90 billion between 1990 and 2001, accounting for almost half of all electricity sector 
investments in developing countries (World Bank, 2004). European and US-based companies were the largest players. Some of these reformed electricity markets managed to successfully introduce large scale competition in the generation sector, and to significantly reduce the wholesale cost of electricity (Grimston, 2004). This success has been helped by technical developments since the late 1980s, particularly the rise of low capital cost combined cycle gas turbine generators (CCGT) which, along with relatively cheap natural gas prices (notwithstanding the 2004-2008 inflation) have enabled a dramatic reduction in the cost and economies of scale in generation and supply of electricity (Colpier and Cornland, 2002; PeñaTorres and Pearson, 2000). Where these reforms have been adopted in Latin America, they have been mainly, but not exclusively, initiated, directed and part financed by the International Financial Institutions (IFIs), often as an integral part of 'structural adjustment' plans or conditionalities on further loans and financial aid (Williams and Ghanadan, 2006). The shift from public to private ownership and control is the cornerstone of the reform agenda. However, not all countries in Latin America pursued market-driven reforms and in reality there exist a diversity of governance frameworks for national electricity markets, as exemplified in this article by Argentina, Costa Rica, Cuba and the Dominican Republic. As such, it is relevant to conduct a comparative analysis of the key financial and economic barriers to technology transfer in these four countries, assessing the main conclusions against each country's existing electricity market and regulatory frameworks. Here, the main focus is on the incentives for investment (private or public) in low-carbon generation technologies.

\section{Latin American electricity sector emissions}

In 2008, $\mathrm{CO}_{2}$ emissions from the Latin America and Caribbean region (LAC) totalled 1530.6 megatons (Mt), accounting for just $5 \%$ of the global total. While $\mathrm{CO}_{2}$ emissions in the LAC region increased from 3.06 to 3.36 t/CO2 per capita between 2000 and 2008, this was outstripped by economic growth whereby emissions/GDP decreased from 0.75 to $0.68 \mathrm{Gg}$ 
CO2/million USD. However, between 1990 and 2006, the carbon content of energy consumption in the LAC region increased from 2.82 to $2.89 \mathrm{Gg} \mathrm{CO}_{2} / 10^{3}$ boe, reflecting a greater overall dependence on more carbon-intense 'fossil fuels' (Sheinbaum-Pardo and Ruiz 2012).

With regard to the GHG emissions from the electricity sector reforms, there remains little evidence to indicate that free markets are an inherently cleaner mechanism through which to manage and deliver supplies. While many countries have reported significant reductions in technical losses due to more waste-conscious private operators, it is also their primary concern to increase sales revenue, which equates to greater consumption, hence emissions. It so happens that much of the new generation capacity in reformed markets is powered by the combustion of natural gas, a cheaper and less carbon intense fossil fuel than coal or oil, and so market reforms have often been held up as 'green', especially in many OECD countries that already had a predominant fossil-fuel base (Haselip, 2007). But the emphasis is on 'cheaper' because there is no inherent reason why the market should choose a cleaner fuel to power electricity generation, and indeed the opposite is often the case, especially in low-income countries that have significant reserves of coal, such as India (Bhattacharyya, 2007). Focusing on the electricity sector, Ruiz-Mendoza and SheinbaumPardo (2010) analysed four Latin America countries (Argentina, Brazil, Colombia and Mexico), all of which had undergone a process of industry privatisation deregulation, and found that these market-based reforms did not lead to a reduction in $\mathrm{CO}_{2}$ emission per MWh. Indeed, their analysis revealed that $\mathrm{CO}_{2}$ emissions from electricity generation increased in all countries apart from Colombia, reflecting a greater dependence on fossil fuels for new electricity generation. 


\section{Technology Needs Assessments (TNAs)}

The Technology Needs Assessments (TNAs) aim to assist developing countries in identifying priority mitigation and adaptation technology needs, and analysing the barriers to transfer, access and implementation of these technologies. On the analytical side, a clear and robust methodology based on the application of wide ranging criteria was developed and applied to a limited number of key sectors in all countries, adapted by countries to take into account national circumstances, based upon Multi-Criteria Decision Analysis (MCDA).

Unlike the first generation of TNAs conducted in the early 2000s, the new round placed a greater emphasis on the analysis of market barriers to the transfer and diffusion of individual technologies prioritised by countries, followed by detailed plans to remove / overcome these barriers, i.e. specific policies and actions implemented by governments, businesses consumer groups (where relevant) and civil society. As such, the new round of TNAs had a strong emphasis on involving national stakeholders, sector-specific experts, and high-level government and private sector representatives in order to ensure that the project's findings are appropriate, realistic (i.e. implementable) and endorsed by local communities and government ministers alike. Within the scope of the new round of TNAs, countries were recommended to focus on 2-4 sectors and to prioritise a similar number of technologies within each sector. The rationale for conducting a more focused study reflected the emphasis placed on the subsequent stages of the project work, which involved an in-depth analysis of the barriers facing the identified technologies and the development of a 'Technology Action Plan', i.e. a detailed road-map for creating an enabling framework for the diffusion of the prioritised technologies.

The TNAs considered in this paper have been conducted in Argentina, Costa Rica, Cuba and the Dominican Republic. The processes have been nationally driven, where the Ministry of Science, Technology and Innovation (MinCTIP), Ministry of Environment, 
Energy and Telecommunications (MINAET), Ministry of Science, Technology and Environment (CITMA), and the Ministry of Environmental and Natural Resources (MMARN) oversaw the work in the four countries, respectively. The results of the prioritization and key barriers for the transfer and diffusion of the prioritised technologies are shown in annex 1 and 2.

\section{Argentina}

Argentina's GHG emissions from the three sectors covered in the TNA process (energy, agriculture and waste - excluding LULUCF) totalled $282 \mathrm{MtCO}_{2}$-eq in 2000 (República Argentina, 2009), accounting for 95\% of total national emissions. This figure had risen to 311 $\mathrm{MtCO}_{2}$-eq by 2005 and BAU projections for 2030 show that these emissions will grow a further 89.8\% against the 2005 baseline, to a total of $591 \mathrm{MtCO}_{2}$-eq (Fundación Bariloche, 2008). Prior to market liberalisation, the majority of installed capacity in the Argentine electricity sector was hydro-based. Since the early 1990s, the majority of new generation capacity has been thermal, mostly utilising the country's abundant natural gas. This transition, from predominantly hydro to thermal-based generation, has resulted in a higher share of national GHG emissions coming from the electricity sector, although the efficiency of the country's thermal plants increased by $0.9 \%$ between 2000 and 2009, averaging a relatively high 41\% in 2009 (Enerdata, 2011). Overall $\mathrm{CO}_{2}$ emissions per kWh generated $\left(\mathrm{CO}_{2} / \mathrm{kWh}\right)$ grew $0.3 \%$ between 2000 and 2009, contributing 25\% of national emissions (IEA, 2012).

The restructuring of Argentina's state-owned electricity enterprises began in early 1992 with the passage of the Electricity Act (Federal Law $N^{0}$ 24,065), after which the three stages of production (generation, transmission and distribution) were vertically disintegrated. Generation became competitive, with transmission and distribution markets operating as regulated private monopolies (Chisari et al, 1999; ENRE, 1997). The Wholesale Electric Market (MEM) that supplies 93\% of Argentina's demand has an installed capacity of 24,352 
MW (as of 2008), of which $54 \%$ is thermal, $42 \%$ hydroelectric, and $4 \%$ nuclear (CAMMESA, 2009). Private-sector investments in the electricity sector since market reform totalled US $\$ 12.5$ billion, up to the economic crisis of 2001/2, of which $60 \%$ constituted new (i.e. non-purchase) investments, with much of this coming from foreign investors (CAISE, 2002).

In accordance with the 1992 Electricity Law 24,065, the Department of Energy (which exists within the Ministry of Economy) is responsible for establishing regulations and industry policies, including rules on technical dispatching, the calculation of wholesale generation prices, and settling appeals made against the regulatory agencies. The market regulator, ENRE, is charged with ensuring private companies comply with this law, imposing appropriate sanctions, making sure concession agreements are carried out, preventing anticompetitive behaviour and monitoring service quality. ENRE's original function was also to establish bases for calculating regulated rates and ensuring that they were applied. Fundamentally, the regulatory mechanism for distribution prices operates on an RPI-x basis where productivity gains ' $x$ ' were proposed to be adjusted every 5 years. During the decade after the country's economic crisis, the government implemented a 're-reform' agenda for public services, whereby the majority of privatised utilities continued to be owned and managed by private actors, albeit with greater regulatory oversight and public policy intervention to incentivise energy efficiency and investment (both private and public) at a time when tariffs were frozen and hence relatively cheap (Haselip and Potter, 2010).

While the federal government legislated a feed-in tariff (FIT) for renewable energy generation technologies, which became operational in 2009 under National Decree 5620/ 2009, the value and structure of the FIT is unlikely to provide sufficiently strong economic incentives for large-scale investment in grid-connected renewable energy technologies (RETs) generation. Argentina's FIT caps support for RET installations of up to $30 \mathrm{MW}$ 
capacity, thus seemingly ideal for SMEs that were the focus of the country's TNA analysis (see appendix 2). However unlike many other FIT policies which offer a clear, fixed, tariff per MWh supplied to the grid, eligible generators in Argentina are paid a maximum 'premium payment' of \$US $0.004 / \mathrm{kWh}$ (for non-PV technology) on top of the wholesale electricity price, for up to 15 years. While this is designed to make tariff support more realistic, i.e. linked to the market price of conventional generation, it simply does not provide sufficient economic incentive to invest in most RETs. For example, the market spot-price for a MWh of electricity on the wholesale market averaged \$US 52.4/MWh in 2009. The maximum FIT for non-PV technologies adds just \$US 4 to this figure, whereas, for example, recent wind power projects are calculating their costs at between \$US 120-158 per MWh (Jacobs et al, 2013). As such, the success of the liberalised electricity generation market, where wholesale prices fell by nearly 50\% during the first 5 years after reform from US\$ 48.76/MWh in 1992 to US\$ 25.67/MWh in 1997, is itself a fundamental barrier to RET generation.

However while low electricity prices serve to benefit economic growth in the short run, these prices have only been made possible by an increasing dependence on natural gas which is, ultimately, unsustainable hydrocarbon energy. More to the point, Argentina's domestic production of natural gas is down 10\% from its peak in 2006 and, importantly, the country became a net importer in 2008 (IEA, 2013), pushing up prices. While the government hopes to develop Argentina's shale gas reserves, which some experts estimate are the world's third largest after China and the US, proven natural gas reserves declined by 50\% from 2002 to 2012, to a total of 13.4 trillion cubic feet (Tcf). This is a worrying trend for the electricity sector which accounts for approximately 33\% of Argentina's total natural gas consumption. Acute shortages of natural gas during the winter months create price volatilities, and underline the sense of investing in CHP technology, as prioritised in the TNA (see appendix 1), when heat demand is at its highest. In conclusion, while the long-term trend for wholesale 
electricity prices appears to be upward, there exist minimal financial incentives to invest in grid-connected RETs in the short term, where a significant gap divides the value of the market spot price + FIT from the present per MWh cost of RET generation.

\section{Costa Rica}

The contribution of Costa Rica to global greenhouse gas emissions (GHG) is negligible. The country emitted about 7.9 $\mathrm{MtCO}_{2}$-eq in 2000 and $8.8 \mathrm{MtCO}_{2}$-eq in 2005, including emissions from land-use change, equal to $0.02 \%$ of global emissions. The energy sector, which includes electricity generation and transmission, is the primary contributor to national GHG emissions. In 2005, the energy sector emitted about $5.7 \mathrm{MtCO}_{2}$-eq (MINAET, 2009), equivalent to 65\% of the country's total emissions. In 2007, the government of Costa Rica committed to become the first carbon neutral country by 2021, thus focusing their attention on the transfer of lowcarbon technologies to the energy sector.

The electricity sector in Costa Rica relies almost entirely on clean energy sources. However Costa Rica imports fossil fuels, mainly petroleum used in the transport sector and in 2011 the national primary energy supply came 94\% from renewables and 6\% from nonrenewable sources. In 2011, 91\% of electricity was generated from renewable sources, mainly hydroelectric. Over the last few years, the quality of electricity supply has deteriorated, with blackouts and rationing, combined with tariff increases driven by a lack of market-based pricing. As such, the main risks and challenges that the electricity sector has to cope with are market vulnerability due to the increasing share of imported fossil fuels in the primary energy mix, low investments in infrastructure, minimal market competition and increasing electricity demand. At current levels of demand growth it has been estimated that generation will have to double from 1,960 MW in 2006 to 3,852 MW in 2021 (REEGLE, 2012). 
In Costa Rica, there is no specific legislation covering the electricity sector. Instead, the generation, transmission, distribution and retail of electricity are regulated by numerous laws that constitute the legal framework and identify the rights, roles and responsibilities of public and private stakeholders. In order to stimulate the use of renewable energy sources, the government put in place a financial, regulatory and policy framework including tax exemptions on renewable energy equipment. Electricity generation is mainly in the hands of the State through the Costa Rican Institute of Electricity (ICE) and the National Company of Power and light (CNFL). ICE is also in charge of electricity Transmission and operates the National Electric System (SEN). The distribution of electricity is largely managed by ICE and CNFL though various municipal companies, though cooperatives are also involved in the generation and distribution of electricity. In addition private companies, including those that own and operate small hydroelectric installations, sugarcane refineries and wind turbines also supply electricity to the grid, though this electricity must be sold to ICE who then transmits to distributors (REEGLE, 2012).

Given that more than $90 \%$ of electricity generation already comes from renewable sources, energy efficiency constitutes the greatest opportunity to address emissions reductions in the energy sector. Following this logic, the Costa Rican TNA focused more on demand-side technologies to increase energy efficiency. Addressing energy efficiency is also a means to reduce future demand for addition generation capacity, which would most likely have to be met by non-renewable sources. Energy efficiency in the energy sector is thus an opportunity for both emissions reduction and energy savings. However many barriers were identified in the TNA process that impede investments in energy efficiency. Costa Rican households spend $2 \%$ of their income on electricity, one of the lowest rates in the region, thanks to the country's higher per capita income and relatively low power prices owing to the large share of hydropower generation. Electricity tariffs are thus relatively low and constitute 
a disincentive for consumers to pursue energy efficiency measures. This is exacerbated by the fact that second hand low-efficiency equipment is widely available at low prices.

Another important barrier identified in the TNA is the lack of financial products tailored to energy efficiency investments. In general, the banks lack qualified personnel to assess energy efficiency projects and therefore such projects depend upon the payment capacity of the client and do not explicitly take into account the cost savings of the projects. Finally, although tax breaks exist for the importation of efficient materials and equipment these have had a low impact, which is also attributed to the readily available supply of low cost, second hand equipment.

As previously mentioned, one of the government's key strategic objectives is to become a low GHG emission economy, which is laid out by the National Strategy for Climate Change (ENCC) and the target of reaching national carbon neutrality by 2021. To reach the carbon neutrality objective, a restructuring of the electricity sector is thus needed from a technological, policy and regulatory point of view. At present most investment in the electricity sector is made by the State. As such, the design and implementation of new policies, regulations and financial incentives will be needed in order to attract private sector investments in renewable technologies. At the same time electricity could be allowed to increase slowly so that consumers are incentivised to use energy in a rational manner, thus off-setting the risk of rapid future demand growth that would otherwise have to be met by non-renewable sources (Pratt, 2010).

\section{Cuba}

The contribution of Cuba to global greenhouse gas emissions (GHG) is low, which, at 36.4 $\mathrm{MtCO}_{2}$-eq, accounted for approximately $0.1 \%$ of total global emissions in 2004, excluding emissions from land-use change and forestry (CITMA, 2013). The energy sector, which includes electricity generation and transport, is the largest contributor to the national GHG 
emissions, making up 71\% of total gross emissions. However, Pérez et al. (2012) have shown that the $\mathrm{CO}_{2}$ produced from electricity generation will increase by $150 \%$ above 2010 levels by 2040 , even if renewable energy makes up $50 \%$ of the generation capacity, reflecting the country's high dependence on oil for electricity generation. It is thus important to consider mitigation opportunities in the electricity sector, which also stand to offer strategic and economic benefits by diversifying the national energy mix and decreasing Cuba's dependence on imported fossil fuels.

In 2011, domestic electrification stood at $97.7 \%$ and gross electricity output totalled $17,754 \mathrm{GWh}$ of which less than $1 \%$ was generated from renewable energy sources (ONE, 2012). The electricity sector in Cuba is facing significant challenges due to a high reliance on oil and gas and a shortage of hard currency to investments in new infrastructure and finance the implementation of programmes for the rational use of energy. In addition, transmission lines throughout the country are susceptible to damage from tropical storms and hurricanes.

The Cuban economy is centrally planned, overseen by the Cuban government, though there is significant foreign investment and private enterprise in some economic sectors, such as tourism. As with all public services, the electricity sector is governed and controlled by the State. The high proportion fossil fuel-based generation results in high, volatile, costs and very high carbon emission. Many financial and economic issues have been identified in the TNA process as key barriers impeding investments and development of renewable technologies in this sector. These include consumer tariffs for electricity that are highly subsidised, although this information is difficult to find and verify, which undermines external efforts to analyse the internal economic efficiency of the country's electricity sectors. In addition, external factors, such as Venezuelan supplies of cheap oil act to further distort the real economic cost of the electricity sector. Also need to comment on the dual currency in Cuba including the 'convertible peso', which is pegged to the US dollar. However this 'hard' currency cannot be 
spent outside Cuba, and so the government is obliged to spend it's USD and EUR reserves (which are received from exports and converted at state banks from remittances and tourists) in order to purchase equipment and hardware for infrastructures and industries, including the electricity sector. At the same time, consumer tariffs are paid from in Cuban pesos which have a lower value (CITMA, 2013). The exchange rate over the last years has ranged from 20-25 Cuban pesos to 1 USD. In this context, the Cuban government lacks liquidity to invest in its own renewable energy programmes or to purchase and maintain equipment for electricity generation, transport and distribution.

One of the weaknesses in the electricity sector in Cuba is the lack of opportunities for private sector participation and competitiveness, which means that there are no purely largescale private businesses. This was identified as a barrier to the transfer of low-carbon technology in the TNA process. However, in recent years, the Cuban government has tried to attract foreign private sector investments through the creation of mixed public-private enterprises. In this scheme, the foreign private party would bring the funds and the technology. Here, there is a strong element of speculation on behalf of investors, i.e. that the pursuit of low-cost assets and business partnerships may become highly profitable if and when the national economic model becomes more liberalised and integrated into to the global economy. Nonetheless, attracting 'sensible' foreign capital remains difficult as Cuba is still considered as a high-risk investment environment due to the commercial, economic, and financial embargo imposed by the United States. It should be noted that the same embargo acts as a major constraint to access many technologies and this has also been identified as an important barrier impeding access to renewable energy technologies.

In Cuba, there is no specific law or legal framework for the electricity sector, including a lack of any legal framework for the development of renewable energy. Although incorporating renewable sources of energy into the energy mix has been a priority since the 
early 1990s, there has been minimal progress and so the government is determined to accelerate the process. Currently, many feasibility studies of decentralized (off-grid) energy sources are underway in order to increase the energy security of the country and to provide electricity access to the non-electrified population. These include technologies such as smallscale wind, biomass, photovoltaic panels, mini-hydropower plants, hybrid systems, and biogas. The government has also launched large programs to restructure the electricity sector in order to address the power crisis, such as the "Revolución Energética” launched in 2006. The Revolución Energética refers to a set of measures to address the generation, distribution and demand side aspects of the electricity market. It focuses in particular on energy efficiency and conservation; increasing the availability and reliability of the national electric grid; incorporating more renewable energy technologies into their energy portfolio; increasing the exploration and production of local oil and gas; and expanding the role of international co-operation. Under this programme Cuba became the first country in the world to eliminate the use of inefficient incandescent light bulbs, which, although not primarily intended to reduce GHG emissions, has had this effect.

Until 2012, the institutional framework of the energy sector in Cuba differed from that of most other countries in that it lacked a Ministry of Energy. The Ministry of Economy and Planning (MEP) was responsible for the coordination of the Energy Commission, which in turn was responsible for the formulation and monitoring of the national energy strategy, including the promotion of energy efficiency and the use of renewable energy sources. However in February 2012, the Council of Ministries created the Ministry of Energy and Mines as a result of the transformation of the former Ministry of Basic Industries (MINBAS), which, among other function, had previously controlled the National Electric Union. Among its function, this new Ministry assumed responsibility for all activities related to the electrical sector. This can be considered as a first key step in the formalisation of a national energy 
policy and in the restructuring of the governance framework, which could lead to the development of new laws to incentivise investment in renewable energy and, energy efficiency.

\section{Dominican Republic}

The contribution of Dominican Republic to global greenhouse gas emissions (GHG) is relatively low, in both absolute and per-capita terms. In 2000, the country emitted about 27.7 $\mathrm{MtCO}_{2}$ including emissions from land-use change. However the carbon intensity of the country is relatively high about $0.5 \mathrm{~kg} \mathrm{CO}$-eq/\$PIBPPP (World Bank, 2010). The energy sector, which includes electricity generation and transport, is the major contributor to the national GHG emissions. In the case of electricity generation, GHG emissions increased from $1.87 \mathrm{MtCO}_{2}$-eq in 1990 to $9.2 \mathrm{MtCO}_{2}$-eq in 2000, thus accounting for $33.2 \%$ of national $\mathrm{CO}_{2}$ emissions. As such, numerous studies have identified the energy sector as having a relatively high potential for GHG emissions reductions in the Dominican Republic (MMRN, 2013). Mitigation opportunities exist on both the demand-side, i.e. by improving energy efficiency, and on the supply-side by introducing renewable and lower-carbon energy technologies in the electricity generation mix. According to the country's TNA, the implementation of mitigation actions in the electricity sector would also have positive macro-economic effects, not least of all in reducing the national dependence on imported fuels.

The electricity sector went through a privatization process at the end of the 1990s when the government sold the electricity generation infrastructure in order to incentive independent, private production. The sector is governed by the General Law of Electricity 125-01 enacted in 2001 and modified by the Law 186-07 in 2007. These laws established the general legal and regulatory framework for the electricity sector and govern the generation, transmission, distribution and retail of electricity. The legal framework also regulates the roles of the institutions related to these functions, where the generation and distribution stages 
are owned and operated by private companies, and transmission and hydroelectric generation to the State. As such, the law recognizes the importance of the private sector in the generation, distribution and retail of electricity, with the objective of expanding and improving the quality and efficiency of the national electricity supply, while giving the regulatory function of the sector to the State (MMRN, 2013). In 2012, 86\% of electricity generation came from the private sector, with approximately 50\% private participation in the distribution sector, while the State governs the whole transmission system. The Dominican Republic can thus be thought of as a hybrid electricity market, where state control and investment decisions continue to steer the market.

The energy sector in Dominican Republic is facing significant supply challenges and the electricity sector is considered to be a major constraint on the country's economic growth. The electricity supply is characterized by frequent and long blackouts, while consumer tariffs are among the highest in the Latin American and Caribbean region. To some extent this reflects the relatively high generation costs, of approximately US\$180 per MWh (compared to less than US\$60 in Argentina). Different factors contribute to this situation, reliance dependence on imported oil. Indeed the country imports $100 \%$ of its fossil fuels, which includes oil products used for electricity generation, making Dominican Republic very vulnerable to price volatilities in the global price of oil. $88 \%$ of the electricity generation is fossil-fuel based; the remainder $12 \%$ generated from renewable sources, mainly hydroelectric plants (SEMARENA, 2012). Other factors are the high commercial risks faced by private generators such as non-payment, the difficulties of pursue large commercial and industrial non-paying customers and the high operating costs of the distribution companies and grid operators (MMRN, 2013). In addition fossil fuels are largely subsidised by the government, thus increases in the global oil price inflate public-sector debt, which in turn undermines the state's ability to invest in public infrastructure, including the energy sector. It has been 
estimated that in 2008, subsidies exceeded US\$ 1 billion, or 3\% of GDP. Decreasing the country's reliance on fossil fuels would thus benefit both energy security and enable emission reductions, while freeing up foreign exchange which could be used instead to purchase lowcarbon energy technologies, offering a means to further break the vicious circle of fossil fuel dependency.

Although Dominican Republic has already invested in hydro technologies, a lot of opportunities are still available for the country to invest in renewable technologies for electricity generation, among other photovoltaic, wind and biomass. Energy efficiency measures represent another way to address emission reductions and cope with energy demand growth and at short term handle the problem of the electricity supply limits. Up to now, policies implemented in relation with promoting private investments for renewable energy in the energy sector, such as the Energy and Special Regimes 57-07 approved in 2007, have been focusing on special fiscal conditions such as tax exemptions and other financial incentives such as FIT for the purchase and installation of grid-connected renewable energy systems although some major barriers remain, hindering sustained growth in the renewables sector (worldwatch, 2012). In the TNA process, the government in the Dominican Republic has placed an emphasis on demand-side management of energy resources, thus prioritising energy efficiency technologies. The lack of financial incentives has been identified as a significant barrier to scaling up investments in EE technologies. In addition, in governmental entities, a shift to EE measure or equipment is highly disincentivated by government subsidised. These barriers are exacerbated by the government's own lack of policy support for EE technologies. As an example, a shift from CFLs, already in wide use as a 'low-hanging fruit' of energy efficiency, to LED lighting systems is hindered by high initial investment cost for the purchase and installation of LED technology in absence of adequate policy and regulatory framework. This, combined with long pay-back period for commercial and 
residential retro-fit technologies for energy efficiency, reflect the relatively low cost of electricity as compared to the high cost of LED lighting systems.

\section{Conclusions}

In this article we have discussed four countries with differing electricity market structures, which influence the governance and incentives required to enable the transfer of low-carbon generation technologies. These range from the largely-private owned and operated market in Argentina to the State-controlled model in Cuba, with the majority State-run system in Costa Rica and the 'hybrid' ownership model in the Dominican Republic, with varying degrees of explicit regulation. These market structures also influence (and are often influenced by) the type of primary energy used in each country, where in Argentina lower-cost natural gas combustion is the generation technology of choice for investors in a highly competitive, liberalised wholesale electricity market. In Costa Rica, the majority of electricity is generated by a few large hydro installations, whereas the island States of Cuba and the Dominican Republic are highly dependent on imported diesel and other oil products for electricity generation.

In common with most of the 32 countries that completed a TNA between 2010 and 2013, a range of non-financial barriers, including various degrees of human and institutional capacity gaps, were highlighted by the four countries analysed in this article. However it is financial and economic barriers and constraints that were deemed by the countries to be of primary importance, which serve to undermine incentives for investment in RETs and/or energy efficiency technologies. Despite the differences between countries and market structures, it is clear that the procurement and uptake or dissemination of low-carbon technologies is faced with financial and economic barriers that transcend issues of private vs. public investment. Specifically, these economic barriers are more a function of the primary energy resources available in countries, as well as various macro-economic settings, than the 
structure of the market per se. In particular, the issue of subsidies also looms large as a 'bigger-picture' barrier to the uptake of RETs, either in the form of government support for imported fossil fuels (as in the case of the Dominican Republic), or as a more targeted subsidy for consumer tariffs (Cuba). Although such subsidies are applied at different levels, they have the same net effect of divorcing tariffs from the cost of generating the electricity, which can lead to bloated public finance deficits and undermine incentives for investment in modern, clean generation technologies and/or rational consumption. In the case of Costa Rica the opposite applies, where the main barrier to investment is RETs is the country's heavy dependence on cheap hydro energy (where maximum capacity has already been reached) that is driving up demand, thus pushing the country towards the use of fossil fuel generation, as the lowest-cost alternative. While it could be argued, on the grounds of market 'efficiency', that demand should be allowed to increase and then slowdown in the face of higher future prices, the government of Costa Rica have the option of imposing energy taxes instead, where revenues could be used to finance support for efficiency technologies, thus providing a duel break on electricity demand growth. From a resource conservation point of view, that would appear to be the most efficient, rational, policy option.

Cuba's political-economic context is a 'special' case that presents a seemingly unique set of financial and economic barriers to the use of low-carbon technologies. While not wishing to undermine the significance of the trade embargo imposed on Cuba, the main economic challenge concerns the monetary system, where major hard currencies are in short supply in Cuba, though these are needed, by State agencies, to purchase technologies from abroad. Here, some parallels can be drawn with Argentina after their economic and political crisis in 2001 led to a 70\% devaluation of the Peso, which had previously been pegged to the US dollar. In this situation the government chose to freeze electricity tariffs so as to protect consumers from the privatised utilities, most of which were foreign-owned, seeking to 're- 
adjust' their tariffs to compensate for the loss in dollar revenues. While that situation bears little comparison to Cuba, the post-2002 tariff freeze also had the effect of breaking the flow of cutting-edge technologies to Argentina, experienced during the 1990s due to the prohibitive cost of purchasing dollar-priced assets in devalued local Pesos. Overall, the conclusions of the country-led TNA processes indicate that the type and strength of the financial and economic barriers to low-carbon technology transfer transcends the market structures. As such, the natural resource base and/or energy mix in each country plays a more significant role than does the ownership and regulation model of the electricity market. While these are broad-based findings, they correspond strongly to the findings of previous major studies on the relationship between electricity market structures and technology transfer, and are likely to contribute to both technical and political debates framed by the Technology Mechanism of the UNFCCC. 
Annex 1 - Results of the prioritization of mitigation technologies in the electricity subsector in Argentina, Costa Rica, Cuba and Dominican Republic (taken from official TNA reports)

\begin{tabular}{|l|l|l|l|l|}
\hline & Argentina & Costa Rica & Cuba & Dominican Republic \\
\hline 1 & Steam Turbine & $\begin{array}{l}\text { Conservation and energy } \\
\text { efficiency in industrial } \\
\text { and residential sectors }\end{array}$ & $\begin{array}{l}\text { Combined cycle with } \\
\text { gas (CCGT) }\end{array}$ & $\begin{array}{l}\text { Use of more efficient } \\
\text { equipment (efficient } \\
\text { light bulbs - LED) }\end{array}$ \\
\hline 2 & Gas Turbine & $\begin{array}{l}\text { Cleaner Electric } \\
\text { expansion plan } \\
\text { (diversification of the } \\
\text { energy matrix in Costa } \\
\text { Rica) }\end{array}$ & $\begin{array}{l}\text { Switch to gas in thermal } \\
\text { generation plants }\end{array}$ & $\begin{array}{l}\text { Use of biomass for } \\
\text { electricity generation }\end{array}$ \\
\hline 3 & $\begin{array}{l}\text { Otto Internal } \\
\text { Combustion Engine }\end{array}$ & $\begin{array}{l}\text { Distributed generation } \\
\text { system (from water, } \\
\text { wind, sun or wastes) }\end{array}$ & $\begin{array}{l}\text { Micro/mini/medium- } \\
\text { hydroelectric plant }\end{array}$ & Photovoltaic \\
\hline 4 & $\begin{array}{l}\text { Diesel Internal } \\
\text { Combustion Engine }\end{array}$ & $\begin{array}{l}\text { Combined cycle turbines } \\
\text { with integrated } \\
\text { gasification using forest } \\
\text { biomass }\end{array}$ & Wind \\
\hline 5 & Cheng Cycle & $\begin{array}{l}\text { Condensing-extraction } \\
\text { steam turbine with } \\
\text { bagasse }\end{array}$ & $\begin{array}{l}\text { Modification of plant to } \\
\text { switch from diesel or } \\
\text { bunker C to natural gas }\end{array}$ \\
\hline 6 & $\begin{array}{l}\text { External Combustion } \\
\text { Gas Turbine }\end{array}$ & $\begin{array}{l}\text { Organic Rankine } \\
\text { Cycle Engine }\end{array}$ & $\begin{array}{l}\text { Grid-connected wind } \\
\text { power }\end{array}$ & Solar thermic \\
\hline 7 & & Grid-connected solar PV & $\begin{array}{l}\text { Micro-hydroelectric } \\
\text { plant }\end{array}$ \\
\hline
\end{tabular}


Annex 2 - Comparative institutions: electricity markets, regulations and key financial and economic barriers to investment in low-carbon technologies (adapted from TNA reports, and secondary sources)

\begin{tabular}{|c|c|c|c|}
\hline ARGENTINA & DOM REP & CUBA & COSTA RICA \\
\hline $\begin{array}{l}\text { - Low tariffs for grid- } \\
\text { connected electricity } \\
\text { and gas } \\
\text { - High capital cost of } \\
\text { investment in } \\
\text { cogeneration systems } \\
\text { - Lack of relevant } \\
\text { financing mechanisms, } \\
\text { including soft loans, to } \\
\text { drive investment in } \\
\text { cogeneration } \\
\text { technologies } \\
\text { - Additional investment } \\
\text { costs associated with } \\
\text { modifications to } \\
\text { infrastructure that allow } \\
\text { for fuel switching (for } \\
\text { example from natural } \\
\text { gas to biomass), and } \\
\text { well new grid } \\
\text { connections. } \\
\text { - Additional costs for } \\
\text { external skilled labour } \\
\text { to operate and maintain } \\
\text { new cogeneration } \\
\text { technologies } \\
\text { - Uncertainty caused by } \\
\text { price volatility of fossil } \\
\text { fuels, in particular } \\
\text { natural gas which is the } \\
\text { primary fuel for } \\
\text { cogeneration } \\
\text { technologies }\end{array}$ & $\begin{array}{l}\text { - Lack of financial } \\
\text { incentives for investors } \\
\text { - High initial investment } \\
\text { cost (for the purchase } \\
\text { and installation of LED } \\
\text { technology) } \\
\text { - Insufficient financial } \\
\text { support from the } \\
\text { government for } \\
\text { investment in EE } \\
\text { - Disincentive for the } \\
\text { technological } \\
\text { shift/change in } \\
\text { governmental entities } \\
\text { - Inexistence of a } \\
\text { guarantee funds to } \\
\text { encourage lending from } \\
\text { private banks }\end{array}$ & $\begin{array}{l}\text { - Insufficient (state) } \\
\text { financial resources } \\
\text { - Limited access to credit } \\
\text { markets } \\
\text { - Absence of positive } \\
\text { financial incentives to } \\
\text { develop capacities in } \\
\text { national industries } \\
\text { - No consideration for } \\
\text { environmental } \\
\text { externalities in the } \\
\text { decisions making } \\
\text { process } \\
\text { - Existing subsidies for } \\
\text { electricity, translating } \\
\text { into very low consumer } \\
\text { tariffs } \\
\text { - The existence of } \\
\text { national monetary } \\
\text { duality undermines } \\
\text { financial stability and } \\
\text { ability to pay for } \\
\text { foreign equipment, } \\
\text { often due to a lack of } \\
\text { hard currency } \\
\text { - Lack of liquidity in the } \\
\text { grid operator to make } \\
\text { investments (due to } \\
\text { electricity subsidies; } \\
\text { consumers pay after } \\
\text { use; consumers pay in } \\
\text { Cuban pesos and not } \\
\text { convertible pesos) }\end{array}$ & $\begin{array}{l}\text { - Tax exoneration with } \\
\text { low impact on purchase } \\
\text { for efficient equipment } \\
\text { - High cost of state of the } \\
\text { art technologies, } \\
\text { compared to second } \\
\text { hand equipment with } \\
\text { low efficiency }\end{array}$ \\
\hline
\end{tabular}




\section{References}

Bhattacharyya, S. 2007. Sustainability of power sector reform in India: what does recent experience suggest? Journal of Cleaner Production 15(2):235-246.

Boldt, J., Nygaard, I., Hansen, U., and Trærup, S. 2012. Overcoming Barriers to the Transfer and Diffusion of Climate Technologies. UNEP Risø Centre, Denmark.

Cámara Argentina de Inversores en el Sector Electrico (CAISE). 2002. Electricity in Argentina: A great achievement facing serious problems. Cámara Argentina de Inversores en el Sector Electrico, Buenos Aires.

CAMMESA. 2009. Annual Report. www.cammesa.com/linfoanu.nsf/MINFOANU?OpenFrameSet

Chisari, O., Estache, A., and Romero, C. 1999. Winners and losers from the privatisation and regulation of utilities: lessons from a general equilibrium model of Argentina. World Bank Economic Review 13:357-378.

CITMA. 2013. Evaluación de Necesidades Tecnológicas ante el Cambio Climático - Informe Final TNA Mitigación, $\quad$ República $\quad$ de Cuba. action.org/index.php?option=com_k2\&view=itemlist\&task=category\&id=48:cuba

Colpier, U. and Cornland, D. 2002. The economics of the combined cycle gas turbine - an experience curve analysis. Energy Policy 30(4):309-316.

Enerdata. 2011. Argentina energy efficiency report in trends in global energy efficiency. $\quad$ www.enerdata.net/enerdatauk/press-and-publication/publications/2011-trends-in-global-energyefficiency.pdf

Ente Nacional Regulador de la Electricidad (ENRE). 1997. Reestructuración y Regulación del Sector Eléctrico. Seminario Internacional, Buenos Aires, Noviembre 1995. 
Fundación Bariloche. 2008. Argentina: Diagnóstico, Prospectivas y lineamientos para definir Estrategias $\begin{array}{lllll}\text { posibles } & \text { ante } & \text { Cl } & \text { Climático. } & \text { Buenos }\end{array}$ Argentina. www.endesacemsa.com/interactivo/descarga/Capitulo2.pdf

Grimston, M. 2004. Generating Profits? Experience of liberalised electricity markets. Imperial College Press, London.

Haselip, J. 2007. Optimising Reform: The Sustainability of Electricity Market Liberalisation in Less Developed Countries. Journal of Cleaner Production 15(2):109-252.

Haselip, J. and Potter, C. 2010. Post-Neoliberal Electricity Market 'Re-Reforms’ in Argentina: Diverging from Market Prescriptions? Energy Policy 38(2):1168-1176.

IEA. 2012. World Energy Outlook. www.worldenergyoutlook.org/publications/weo-2012/

IEA. 2013. World Energy Outlook. www.worldenergyoutlook.org/publications/weo-2013/

Jacobs, D., Marzolf, N., Paredes, J.R., Rickerson, W., Flynn, H., Becker-Birck, C., and Solano-Peralta, M. 2013. Analysis of renewable energy incentives in the Latin America and Caribbean region: The feed-in tariff case. Energy Policy 60:601-610.

Karakosta, C., Doukas, H., and Psarras, J. 2010. Technology transfer through climate change: Setting a sustainable energy pattern. Renewable and Sustainable Energy Reviews 14(6): 1546-1557.

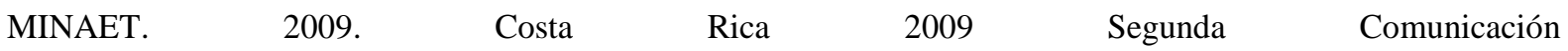
Nacional. http://unfccc.int/resource/docs/natc/cornc2.pdf

MMARN. 2012. Síntesis de la Evaluación de Necesidades Tecnológicas (ENT) y plan de acción de la ENT para la mitigación en el sector energético de la República Dominicana- Informe Final TNA Mitigación, República 
action.org/index.php?option=com_k2\&view=itemlist\&task=category\&id=49:dominican-republic

ONE. 2012. Anuario Estadístico de Cuba 2011, Minería y Energía, 10.14 - Indicadores seleccionados de electricidad. www.one.cu/aec2011/esp/10_tabla_cuadro.htm

Peña-Torres, J. and Pearson, P. 2000. Carbon abatement and new investment in liberalised electricity markets: a nuclear revival for the UK? Energy Policy 28(2): 115-135.

Pérez M.D., López L.I. and Somoza C.J. 2012. Evaluación de opciones de mitigación de gases de efecto invernadero en el sector energético cubano. CUBAENERGIA, ISBN 978-959-7136-88-0

Popp, D. 2011. International Technology Transfer, Climate Change, and the Clean Development Mechanism. Review of Environmental Economics and Policy 5(1): 131-152.

Pratt, L., Rivera, L., and Sancho., F. 2010. Opciones de Mitigación de Emisiones de Gases de Efecto Invernadero en Costa Rica: Hacia la Carbono Neutralidad en el 2021. www.incae.edu/ES/clacds/publicaciones/pdf/needs.pdf

REEGLE. 2012. Energy Profile Costa Rica. www.reegle.info/countries/costa-rica-energy-profile/CR

República Argentina. 2009. Segunda Comunicación Nacional de la República Argentina a la Convención Marco de las Naciones Unidas sobre Cambio Climático http://unfccc.int/resource/docs/natc/argnc2s.pdf

Ruiz-Mendoza, B.J., and Sheinbaum-Pardo, C. 2010. Electricity sector reforms in four Latin-American countries and their impact on carbon dioxide emissions and renewable energy. Energy Policy 38: 6755-6766.

SEMARENA 2009. Segunda Comunicación Nacional, Proyecto Cambio Climático 2009. http://unfccc.int/resource/docs/natc/domrepnc2.pdf 
Sheinbaum-Pardo, C. and Ruiz, B., J. 2012. Energy context in Latin America. Energy 40: 39-46.

Williams, J.H. and Ghanadan, R. 2006. Electricity reform in developing and transition countries: A reappraisal. Energy 31(6-7): 815-844.

World Bank. 2004. Private Participation in Infrastructure: Trends in Developing Countries in 1990-2001. World Bank, Washington DC.

World Bank. 2010. De la crisis financiera internacional al crecimiento para todos, República Dominicana. World Bank, Washington DC.

Worldwatch. 2012. Sustainable Energy Roadmaps: Guiding the Global Shift to Domestic Renewables. Worldwatch report 187.

Yi-Chong, X. 2006. The myth of the single solution: electricity reforms and the World Bank. Energy 31 (6-7): 802-814. 